\title{
Translating Yemeni cartoons into English: A Systemic Functional Linguistics approach
}

\author{
Tawffeek Abdou Saeed Mohammed Al-Kenani \\ Linguistics Department, University of the Western Cape, Bellville, South Africa | English Department, Taiz \\ University, Yemen. \\ E-mail: tawffeek@gmail.com
}

Felix Banda

Linguistics Department, University of the Western Cape, Bellville, South Africa

E-mail: fbanda@uwc.ac.za

\begin{abstract}
This study deals with the problems involving translating Arabic cartoons into English and the strategies that can be adopted by a translator to make them more accessible and more targetaudience friendly. It uses an approach based on Halliday's Systemic Functional Linguistics (SFL; Halliday 1985/1994; Halliday and Matthiessen 2004). The concept of equivalence is revisited within the framework of SFL to include register analysis and the three strands of meaning or metafunctions. The study is based on a number of Yemeni cartoons that have been translated in the Yemen Times, a prominent English-language Yemeni newspaper. The study concludes that if a cartoon is to be translated in such a way that the target cartoon sounds as natural and entertaining to the target audience as the original, the translator should take into account the context of culture, the context of situation (i.e., register analysis) and the metafunction(s) involved in the source cartoon and tries to render them as far as possible in the target language. In addition, a cartoon is a multi-semiotic genre in which both text and image go hand in hand. The image-text semantic relation in this multi-model discourse can facilitate the comprehension of the context and the interpretation of the schemata of the cartoons more clearly. The translation of a cartoon cannot be achieved unless the two codes are considered.
\end{abstract}

Keywords: Cartoon; translation; equivalence; SFL; context; register; metafunction; ideational; interpersonal; textual

\section{Introduction}

Cartoons have become an interesting way to tackle several issues of society, and they touch the hearts of millions of people across the globe. It is not surprising then that various media outlets have utilised the power of cartoons, and they devote special sections to them in their 
newspapers, magazines, tabloids, etc. Cartoons are not also the monopoly of formal media; they have also been introduced in the works of graffitists and the textbooks of pupils at schools.

Cartoons can deal with different social, economic, religious and political topics in a very simple manner. They appeal to people of all ages and they capture the attention of all. However, it might be extremely difficult to understand the message of a particular cartoon. A mistaken notion about cartoons is that they are designed to be humorous but this is not always the case. In addition to their entertainment function, cartoons are likely to educate readers, inform them, arouse their feelings and instruct them to act positively. As Corstange (2007: 293) argues, "cartoons provide a venue for political speech, and, in the context of societies which suffer from shaky freedoms of expression, provide also a venue to express political dissent."

The current study deals with the problems of translating Arabic cartoons into English, and the strategies that can be adopted by a translator to make the translation more accessible and communicative to the target audience. Cartoons are treated as a multimodal genre in which both visual and written modes need to be considered during the process of translation. We will therefore attempt a holistic approach to translating cartoons that takes into consideration the analysis of meaning potential across the visual and written modes. Although the study deals with Yemeni cartoons, the cartoons analysed in the study are used as microcosms of Arabic cartoons in general, because Arab cartoonists tackle more or less similar socio-cultural and political topics (Al-Labād and Hajāj 2005). Due to the novelty of this genre in Yemen and many other Arab countries, we first discuss its significance and present a brief history of its development in the Yemeni context.

\section{The Evolution of Yemeni Cartoons}

In Yemen and the Arab world at large, cartoons have undergone a tremendous change as far as the topoi (i.e., topics) they present are concerned. Due to the dictatorship of some Arab regimes, cartoons are used to avoid censorship or enragement from the regimes. A cursory look at some of the widely circulated Arab newspapers shows clearly that politics is an issue that cartoonists cautiously avoid. Some of the Arab newspapers (e.g. Al Ahram, Al Diyar and Al Thawrah) may touch upon heated international events but not local political issues. This is because cartoons are likely to bring much trouble to their artists, and Arab cartoonists have a bitter experience in this regard. Naji Al-Ali, a Palestinian political cartoonist, was murdered in 1987 in England. It is thought that his cartoons that exposed dirty politics in the Middle East cost him his life. It is even argued that one of his last cartoons was solely responsible for his death (Zyglis 2003: 4). In a similar vein, the Jordanian cartoonist, Nahid Hater, was killed in 2016 after the publication of a cartoon (Al Minawi 2016), and the Moroccan cartoonist, Khalid Kadar, was threatened with his life for re-tweeting Hater's cartoon (RT Arabic 2016). However, that did not scare some Arab cartoonists who continue to practise this art even if it might cost them their lives. Describing his mission as a cartoonist and the challenges that he encounters, Kamāl Sharaf, a Yemeni cartoonist, says in an interview with La Voix du Yémen:

I am still continuing in the same path, exposing the truth and revealing the real image of the religious clerics and sheikhs in Yemen. The last threat I had was from the case of Sheikh Ali Al Awadhi and the murder of two youths (Khalid Al-Khatib and Hassan 
Aman), both in their twenties. I drew Al Awadhi and under his beard were the two young victims in hiding. The cartoon spread like a virus.

(Sharaf 2013)

It may be argued that caricature is an ancient art in Yemen and in Arabia. Drawings found on ancient discovered stones which date back more than three thousand years can be regarded as a precursor to cartoons. However, caricature in its present form is relatively new in Yemen as it dates back to the 1960s. The Yemeni revolutions in the north and the south of the country in 1962 and 1963 respectively, as well as the influence of the Egyptian press that played a vital role in shaping the political scenario in Yemen at the time, have given an impetus to the thriving of this art. One of the earlier Yemeni cartoonists is Abdul-Majeed 'urāsī, who published his cartoons in the Aden-based Al-Sabāh and Funūn Al-Jazīra newspapers. In the 1970s and 1980s, a new generation of cartoonists appeared. To this generation belongs 'Adnān Jum 'ān, who disseminated his cartoons through The 14th October $^{1}$ state-run newspapers, as well as the only Yemeni female cartoonist thus far namely, Jamīlah Al- 'Azānī. The leading newspapers in the north of the country have also paid great attention to cartoons. Mufìd Al-Yūsifi, Abdul-Azīz Ibrahīm, 'Arif AlBadawī, Rashād Al-Sami' $\overline{1}$, Al-Shaybān̄̄ and Kamāl Sharaf have demonstrated their talent through the Taiz-based Al-Jumhüriyah and the Sana'a-based Al-Thaurah newspapers (AlJumhūriyah 2008). However, cartoon art in Yemen reached its high point in November 1992 when a specialised caricature magazine was released by the late Ișām Sa'īd Sālim, which continued to be issued until 2007 (Al-Hayjami 2014). This is the only specialised cartoon magazine in the history of Yemen. The country's move towards democracy after the reunification in 1990 encouraged cartoonists to freely tackle political, social and economic issues.

With the advent of the Arab Spring, political cartoons have come to the forefront and dominated the scene in both electronic and print media of the Middle East. Some daily and weekly newspapers and magazines in Yemen allocate a page for cartoons. Others have a long supplement in which a recap of key events is presented. In addition, famous Arab TV channels such as Al-Jazeera and Al-Arabia have devoted part of their coverage to cartoons depicting current issues in the Arab world. Some English-language Yemeni newspapers (e.g. Yemen Times) used to collect some interesting cartoons from various sources and have them translated into English. The online availability of those newspapers has enabled them to reach a wider international audience which is interested in the Yemeni and Arab socio-political transformations. The topics of the cartoons range from local issues, such as the ousting of some Arab presidents, to regional, national and international issues.

The cartoons analysed in this study all have something in common: all usually use captions or speech balloons, which facilitate the comprehension of the semantic content of the cartoon. However, the caption alone may not suffice to clarify the semantic content of a cartoon. A degree of background knowledge and familiarity with the context is required to get the message across. If that is the case with original cartoons, translating them will be even more challenging and may require some kind of intervention on the part of the translator. If translation is "meaningful records of communicative events" (Hatim 2001: 10), those records of events need to be made clear before translators embark on the translation of a cartoon. This will be difficult if a translator of a cartoon ignores the context of the cartoon under investigation.

\footnotetext{
1 This newspaper is named after Independence Day officially came into being in the south of Yemen on 14 October 1963.
} 


\section{Literature on the translation of comics and cartoons}

Studies on the translation of cartoons are relatively few if we compare them with studies that have been done in neighbouring fields, such as comics and jokes. A cartoon and a comic strip are two different yet related genres. While the former refers to a single panel image tackling a specific issue, the latter is a story which is narrated through a sequence of panel images. From a translational perspective, the translation of cartoons also involves problems that are frequently encountered while translating comics and humour in general. In the following subsection, we will briefly survey some of the studies that involved the translation of comics. Studies on cartoons will be discussed in 3.2.

\subsection{Translation of comics}

Many studies have been conducted on the translation of comics. Hellgren (2007) analysed how translator Sari Luhtanen rendered as subtitles the allusions found in the television show, The Simpsons, from English into Finnish, and to what degree she chose to omit the allusions from the subtitles. Hellgren (2007) used Leppihalme's (1997) classification of translation strategies with a view to finding out how a translator can successfully translate such allusively dense audiovisual material.

Macková (2012) investigated the specifics of comics translation. The study concluded that matters of format, the type of binding, the size of speech balloons, the preference of colour and the graphic techniques are key elements in the translation of comics. Macková (2012) also pointed out that both pictorial and written parts of comics are often so intertwined that the translator needs to consider them both in order to fully grasp and render all the meanings they present.

Koponen (2004) discussed wordplay in Donald Duck comics and their Finnish translations, especially the kind of wordplay that arises from the interaction of the words and images. Koponen argued that the translator should consider the image when translating the text. The study recommended that translators should attempt an analytical examination of what creates the humorous effect. This analysis helps the translator to determine the meanings in the source text, and to evaluate the reproduced effects in the target text. The study claimed that the translator will very rarely, if ever, be able to produce a close translation of the wordplay because wordplay and humour are very closely connected to the source language and source culture.

Finally, “TranscUlturAl: A Journal of Translation and Cultural Studies” devoted a special issue to the translation of comics. The studies included in the issue focus on some theoretical aspects of translation such as the concept of 'faithfulness' or 'fidelity' in translated comics (Abril 2016; Assis 2016). Other studies tackled some technical aspects of translating comics such as the link between comics translating and subtitling (Borodo 2016), and the use of translation annotations to investigate the practice of scanlation (i.e., scanning, translating, and editing comics from one language into another) and its specificities (Fabbretti 2016). One article expands on the pedagogical value of the translation of comics in teaching economic and financial texts (Falco 2016). The remaining articles concentrate on some cultural aspects of comics translation. Aragao (2016) investigates the translation of cultural items and how those can reveal identities and values. Finally, Kenevisi and Sanatifar (2016) have shown the types of difficulties in translating Hergé's Tintin comic in Iran. The study highlights the impact of the Islamic revolution on the cultural activity of comics translation in the country. It analyses three 
translations of the work with a view to demonstrating how comics translation has been moving from a central position to a more peripheral one in the Iranian cultural polysystem.

\subsection{Translation of cartoons}

Compared to comics, there appears to be a dearth of studies on the translation of cartoons. Yakin (1999) discussed the translation of humour with reference to the cartoons in Laman and other popular weekly Turkish magazines. Yakin (1999) argued that the cartoons, which are not strictly political nor crammed with regional issues and accents, are translatable. They could be understood by an outsider with the help of an adequate amount of contextual and cultural background information. Yakin (1999) adds that the amount of contextual information should be carefully decided to meet the needs of the target readership. A translator should not give unnecessary, redundant information because this may corrupt the meaning of the cartoon.

El-Arousy (2007) investigated the problems of translating Egyptian cartoons into English. The study concluded that a translator of cartoons is required to render the cultural distinctiveness of the cartoons, the scripts ${ }^{2}$ expressed in the linguistic component as well as the nonwritten and/or semiotic cues of the drawings, and relate them to the incongruity expressed in the two scripts.

Zanettin (2010) differentiated between the translation of humour in cartoons and the translation of humour in comic strips and comic books, highlighting differences and similarities. Zanettin (2010: 48) argued that humour in cartoons stems from some kind of incongruity within the drawing itself or between visual and written signs, which readers expect. In the case of most comic strips, however, humour is the product of the simultaneous comprehension of the image and the words within the image. Zanettin (2010) argued that humour is never just in the words, as we might see in a cartoon - it is in who says them.

Cui (2012) examined creativity in translating cartoons from English into Mandarin Chinese. The study argued that the translator should try his/her best to provide a creative translation in the target language. In other words, the language of the target cartoon can undergo a certain degree of rewriting so that the translated text sounds natural, educational and entertaining to the target language audience. The study concluded that domestication and cultural adaptation are common strategies adopted by translators in the process of rendering a translated cartoon.

Judickaitè-Pašvenskienè (2014) studied the translation of English idioms in the Lithuanian subtitles of children's cartoons with a view to finding out whether meaning alone or meaning and form takes preference in the Lithuanian translation. The study particularly focused on the processes which take place during the translation of English idioms containing proper nouns. The study concluded that the element of meaning, rather than the composition of meaning and form, takes preference in the Lithuanian translation.

Guyer (2016) discussed some problems regarding the translation of Egyptian political cartoons. The study focused on the rendition of humour and satire in Egyptian cartoons. It also considered the rendition of symbols rooted in local contexts but which were likely to be illegible to target audience. Issues related to puns and tropes were also discussed. Admitting the difficulty of translating cartoons,

\footnotetext{
${ }^{2}$ In cognitive psychology, a "schema” refers to a conventional knowledge structure that exists in memory, and a "script” is a dynamic schema, a series of conventional actions that take place (Yule 2014:132-133).
} 
Guyer (2016: 213) observes that "[t]here is no such thing as a correct or perfect translation. The translator of cartoons is an artist, requiring a diverse toolkit and a clever wit”.

Taran (2014) discussed some cultural, technical and linguistic difficulties of comics and cartoons that the translator encounters. The study focused on the translation of onomatopoeic words and puns. The study also dealt with some technical problems in the translation of comics and cartoons such as limited space, special language, and the interference of publishing houses, that are likely to force a translation either to suit a particular ideology or to boost sales.

It is obvious from the above survey of studies that they either focus on comics, humour in general, or some aspects of cartoons such as wordplay, onomatopoeic words, allusions, and/or colloquial linguistic items, all of which are often used in cartoons but are not specific to them. It may be argued that even humour, which is the main concern of a considerable number of studies, has not been considered properly. As Vandaele (2002:149) puts it clearly:

Whereas the immense practical act of translation itself is [...] increasingly being theorized in what has come to be known as translation studies [...] the combined object of humour translation must have seemed until now so vast, disorientating and dangerous an ocean that few academic efforts were made to theorise the processes, agents, contexts and products involved.

In this study, we are looking for a holistic approach to the translation of cartoons that takes into account the multimodal/multi-semiotic specifics of cartoons and the linguistic features they share with other genres. Our approach is presented in the subsections to follow and it is based on a solid theoretical framework that pays equal attention to the visual and textual dimensions of a cartoon.

In fact, a multimodal translation of a cartoon that preserves the image and characters of the original may look foreignised to the target reader. Cartoons deal with diverse topics and they sometimes tackle issues that may not be understood outside a local community. A translation should enable the target reader to understand the other. The written message, if any, should be domesticated and made clearer to some extent in order to facilitate the comprehension of the meanings inherent in the image that may look a little foreignised. In short, a good translation of a cartoon should not aim for either domestication or foreignisation. As Sun (2011: 163) points out: "[f]oreignization and domestication are indispensable and supplementary to each other and the idea that truly successful translation will depend on the unity of the two methods should be kept as a golden mean in every translator's mind.”

\section{Theoretical framework}

We use an approach based on Halliday's Systemic Functional Linguistics (SFL; Halliday 1994; Halliday and Matthiessen 2004) as a framework for the current study. As Halliday notes, SFL is functional because "it is designed to account for how the language is used. Every text [...] unfolds in some context of use” (Halliday 1994: xiii). A translator should not underestimate the significance of the context while translating this genre in which both visual images and texts, which are deeply rooted in a particular culture, are combined. In other words, a translator is not only required to transfer meanings into a target language alone but into a target culture that is likely to be remote from the source culture. He/she is therefore required to understand the social and cultural contexts of the source text/cartoon. 
Following Malinowski (1923), Halliday emphasises that a text takes place in two contexts: the "context of situation" and "context of culture". While the former refers to the immediate context surrounding a text, the latter refers to the wider context of culture. A context of situation is characterised by a particular register of language (Eggins 2004). "Register", here, refers to a configuration of meanings that are typically associated with a particular situational configuration of Field, Mode and Tenor. Halliday adds that register is a configuration of meanings and thus it should "include the expressions, the lexicogrammatical and phonological features, that typically accompany or release meanings” (Halliday and Hasan 1985: 38-39).

"Field" refers to the social activity in which people communicating are involved, its content or topic (e.g. politics, sports, etc.). "Tenor" is defined as the social relationships of the people involved in the process of communication, while "Mode" refers to the medium and role of language in the organisation of the text (Eggins 2004). The analysis of those aspects is significant when translating any genre that includes cartoons. As Manfredi (2008: 40) states:

A thorough and correct understanding of these three variables is fundamental, we believe, for the translator. A translator who is capable of identifying these different dimensions [Field, Tenor and Mode] and is able to reproduce them in a different language, the [Target Language], is better able to offer a text which is 'functionally equivalent' to the source one, even though the structures be different - because languages are different.

Another aspect of preference for the use of SFL in translation studies resides in the fact that it does not only pay attention to the extra-textual or contextual levels but also focuses on the meaning of a text, which is at the heart of any translation activity. SFL takes into account the relationship between syntax, semantics and pragmatics. It views language "essentially as a system of meaning potential" (Halliday 1978). To put it differently, language is a "resource for making meaning” (Halliday and Matthiessen 2004: 23). The three variables of the context of situation are related to three meaning metafunctions: ideational, interpersonal and textual. Martin (2002: 56) notes that:

Interpersonal meaning is related to the enactment of social relations (social reality), or tenor; ideational meaning is related to the construction of institutional activity ('naturalized reality'), or field; and textual meaning is related to information flow across media (semiotic reality), or mode.

In a cartoon, a translator is not only required to understand the social and cultural source context, he/she is required to reproduce meanings in a target language that is likely to be culturally different. In fact, the interplay of the three strands of meaning or metafunctions is what makes a cartoon more appealing and, at times, funnier. Some cartoons tend to put more emphasis on one of the metafunctions rather than the others. While more prominence is given to the ideational content in some cartoons, the interpersonal metafunction may outweigh the ideational and textual metafunctions in others. In other cases, however, all the metafunctions work simultaneously towards the creation of a humorous effect. We concur with (Todd 2012: 39-40) that

[when considering] the importance of semantic content in what people find funny, it is clear that the ideational metafunction is central to humor. In cartoons where text and 
image interact, the textual metafunction plays a role [...] While the prime source of humor in the cartoon is ideational, the interpersonal metafunction can influence the perceived funniness of this humor. In the words of the old adage: It is not (only) what you say, but how you say it.

It can be argued that if a cartoon is to be translated in such a way that the target cartoon sounds natural and entertaining to the target audience, the translator should take into account the context, the register variables and the metafunction(s) involved in the source cartoon, and try to render them as far as possible in the target language. The use of SFL in the translation of cartoons can, therefore, facilitate a translation that meets both the requirements of creativity and translation adequacy.

In addition, a cartoon is a multi-semiotic genre in which written texts and images go hand in hand. Therefore, a translator needs to account for the multimodal (Kress and Van Leeuwen 2006; Kress 2010) material used in a cartoon to show how the different modes - written texts and images, different font types and font sizes, scripts (Roman and Arabic), colour, etc. - are deployed for meaning making. Multimodal discourse analysis is an offshoot of Hallidayan SFL and social semiotics (Kress and Van Leeuwen 2006; Kress 2010). The image-text relation in this multimodal genre analysis can facilitate a clearer comprehension of the context and the interpretation of the cartoons. This adds an impetus to the use of SFL and multimodality in translating cartoons. Multimodality is based on the assumption that meaning is not only associated with the linguistic mode; rather, it "resides so strongly and pervasively in other systems of meaning, in a multiplicity of visual, aural, behavioural and other codes, that a concentration on words alone is not enough" (Hodge and Kress 1988: vii). The translation of a cartoon cannot be achieved unless the modes used for meaning making are explicated (Kress and Van Leeuwen 2006; Kress 2010). This involves describing how written texts and images complement each other across the expression plane, the content plane (i.e., grammar and discourse strata) and the context plane (i.e., register and genre; see O'Halloran (2005) and (2007)). This also entails accounting for visual-written coherence and intersemiotic cohesive devices such as intersemiotic parallelism (i.e., language and image share a similar form), intersemiotic polysemy (i.e., written and visual components share multiple, related meanings), logical relations between language and images (e.g. intersemiotic comparative relations, additive, consequential and temporal relations; see (Liu and O’Halloran (2009)) that play a role in the comprehension of the topoi of a cartoon and hence its translation (for more details about the above concepts, see (Kress 2010; Kress and Van Leeuwen 2006; Liu and O’Halloran 2009)).

\section{Equivalence in the translation of cartoons}

It would be useful to approach the concept of 'translation equivalence' from an SFL perspective with special reference to cartoons. Equivalence is a key concept in translation studies, and has been a matter of heated debate and discussion among philosophers, linguists, and translation theorists. Their debate has produced a number of dichotomies such as Nida's (1964) "formal vs. dynamic equivalence”, Catford's (1965) “textual equivalence vs. formal correspondence”, and Newmark's (1977) "semantic vs. communicative equivalence”. Other classifications of translation equivalence have been attempted by several scholars. Hatim (2001), for instance, argues that equivalence can be formal, denotative, connotative, text-normative, and pragmatic or dynamic. Baker (1992) suggests a more detailed distinction of the concept of 'equivalence' at the lexical, grammatical, textual and pragmatic levels. 
Our analysis of the concept of 'equivalence' is based in particular on Halliday's (2001) paper, Towards a Theory of Good Translation. In this paper, Halliday (2001:17) emphasises the significance of context and register variables in translation, and adopts a principle of a "hierarchy of values" which he suggests a translator should follow:

Equivalence at different strata carries differential values; [...] in most cases the value that is placed on it goes up the higher the stratum - semantic equivalence is valued more highly than lexicogrammatical, and contextual equivalence perhaps most highly of all.

Equivalence, therefore, for Halliday, is functional and takes into consideration the linguistic and extralinguistic levels as well as the language metafunctions (i.e. ideational, interpersonal and textual). Each of these levels and metafunctions has a value on his scale.

In this sense, the concept of 'equivalence' should be revisited to meet the generic conventions of multimodality (Kress 2010; Kress and Van Leeuwen 2006; Liu and O’Halloran 2009; O’Halloran 2007). Equivalence at the level of register should take into account the mismatches between the Field, Tenor and Mode of the original cartoon and its translation. Equivalence at the ideational metafunction should take into consideration the lexicogrammatical aspects of transitivity (e.g. the processes involved), tense, voice, lexical items, and the like. At the interpersonal level, aspects such as mood, modality, language varieties, style, and evaluative language should be investigated. At the textual level, aspects such as caption brevity, caption authenticity, intersemiotic texture (i.e., cohesive devices between text and image) should be considered.

It is worthwhile to mention that even though we are adopting a multimodal approach to the translation of cartoons, we have found it necessary to integrate it with some translation studies models. House's (1977/1997) model of translation quality assessment, which is based on Halliday's SFL and so is compatible with it, will be used in our register analysis of the cartoons under investigation. House (1997) has identified a number of situational dimensions that can help with a register analysis of any genre. Some of these elements are additional to those expressly stated by Halliday (Munday 2001: 93). For the analysis of Field, a translator should find out the matches or mismatches related to subject matter and social action. As part of her analysis of Field, House (1997: 107) distinguishes between degrees of "granularity" in lexical items according to rubrics of specialised, general, and popular.

In the analysis of Tenor, a translator should consider factors such as the social role relationship or the degree of "emotional charge" between the addressor(s) and the addressee(s) in terms of social power and social distance (House 1997: 108). Another element to be considered in the analysis of Tenor is social attitude. In this regard, House collapses the five styles that she used in her original model (House 1977) - frozen, formal, consultative, casual, intimate - into three: formalconsultative-informal. A third subdivision of Tenor is the writer's or translator's provenance and stance.

The analysis of Mode includes two dimensions, namely medium and participation. Medium can be simple if it is written to be read, and complex if it is written to be heard. Likewise, the participation can either be simple (e.g. a monologue) or complex, such as a dialogue. 


\section{Methodological issues}

\subsection{Data collection}

The data used in this study includes the English translations of six cartoons that were published by a widely-circulated Yemeni newspaper, namely Yemen Times. This newspaper is published in English and it targets international English readers. The original cartoons are in Arabic and they were sketched by two well-known cartoonists, namely Rashād Al-Sami ' $\overline{1}$ and Kamāl Sharaf. The source cartoons cover different political, social and religious issues. They do not only appear in famous state-owned and private newspapers and websites but they also went viral on social media such as Facebook and Twitter. The six translated cartoons were published between June 2012 and May 2015 in the cartoons section of the newspaper. In fact, the tragic ongoing war in Yemen has greatly influenced the dissemination of the Yemeni newspapers and thereby the spread of translated cartoons. Yemen Times, the leading Yemeni newspaper in English, stopped its printed version and it switched to online-only edition. No translated cartoons have appeared on its website since May 2015. Hence, the study uses all the cartoons that were published by the newspaper during the above period (i.e., June 2012 till May 2015). Two of the six cartoons tackle the socio-cultural issues of marriage and the marital relationship, two are political in that they deal with Al-Qaeda and pilgrim trafficking, and the last two cartoons are socio-economical as they tackle water and electricity crises.

In our analysis of the cartoons, we follow the procedures below:

i. First, the source cartoon (SC) is given, and a word-for-word translation of the textual component is provided. For the standardisation of the diacritic marks required when transliterating Arabic, we have used the Roman Transliteration of Arabic Script (ROTAS) software (see transliteration tables in the Appendix);

ii. The target cartoon (TC) is then given;

iii. The cartoon is considered in its context of culture;

iv. An analysis of the discourse semantics of the SC and TC is provided. This is done through the analysis of the three metafunction(s) of the cartoon and its lexicogrammatical aspects;

v. Afterwards, a register analysis of the SC and TC under investigation is attempted, and mismatches - if any - will be shown on the basis of House's (1977/1997) model; and

vi. Finally, a description of problems at the genre level, if any, will be given.

\subsection{Multimodal/-semiotic problems in the translation of Arabic cartoons}

In the following subsection, we present an analysis of the six cartoons and their translations into English with a view to evaluating the kinds of multimodal/-semiotic problems encountered during the translation process.

\subsubsection{Metafunctions analysis of the cartoons}

\subsubsection{Analysis of cartoon 1}

Consider the differing information value given in the cartoon in Figure 1.1, with that in Figure 1.2 below. 


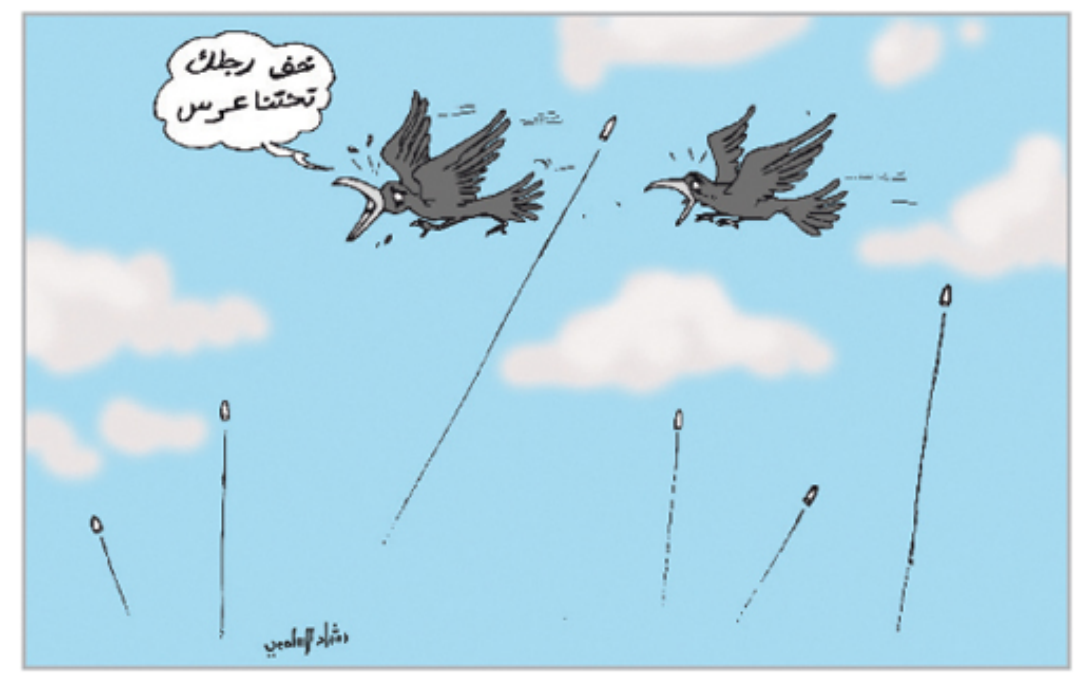

Figure 1.1 (Source: https://www.facebook.com/ALYemenchanel/posts/337133563033927)

\begin{tabular}{|c|c|c|c|}
\hline Khif & rijlak & ti htana & 'urus \\
\hline Lighten & legs your & below us & wedding \\
\hline
\end{tabular}

The above cartoon was translated by the Yemen Times as in Figure 1.2.

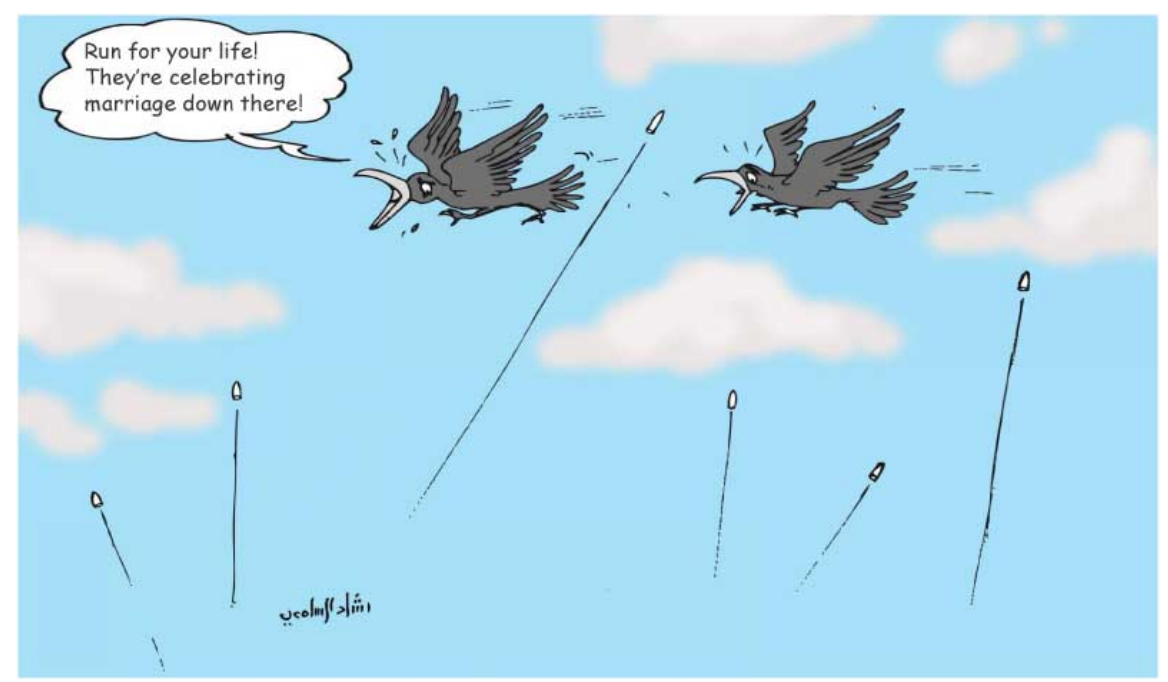

Figure 1.2 (Source: http://www.yementimes.com/)

The TC shows a kind of loss at the ideational, interpersonal and textual metafunctions. Since the target reader may not share the same schematic structures or "script" of marriage as Yemeni society, he/she could find it extremely difficult to comprehend what is meant in the SC. The incongruity of the cartoon and its source of humour can be reflected by considering the three metafunctions as depicted by both the written text and the image. At the ideational level, the interplay between the image and written text shows that there is an existential process that can be interpreted as "On the ground, there is a wedding", and two material processes that can be interpreted as "people are firing guns in the air while celebrating” and "shake/lighten your leg". At the interpersonal level, the bird in the lead is the addressor, and it seems that it is of a higher authority and is more familiar with the situation. This is reflected by the use of the imperative mood khif arjulak ('lighten your legs'). 
In addition, the visual and linguistic features are interrelated in this multi-semiotic cartoon, and constitute a certain type of intersemiotic consequential relation (Liu and O'Halloran 2009; Martin 1992). It would be more apt to render the cartoon as "Lighten your legs, dude. People are celebrating marriage below and they may shoot you dead". Even though "they may shoot you dead" seems self-evident from the visual mode, for those who are unfamiliar with Yemeni customs, we should not expect the common English-speaking reader to be familiar with this schematic pattern of a Yemeni wedding. If it remains unexplained, a culture-specific term (let alone a schematic pattern) may nullify the humour of the cartoon. Hence, the suggested translation preserves the ideational meaning of the original, the interpersonal meanings between the participants, as well as explicating the multi-semiotic relation between the textual mode of the cartoon and its visual mode.

\subsubsection{Analysis of cartoon 2}

In a similar vein, equivalence at the metafunctional levels is not achieved in Figure 1.4.

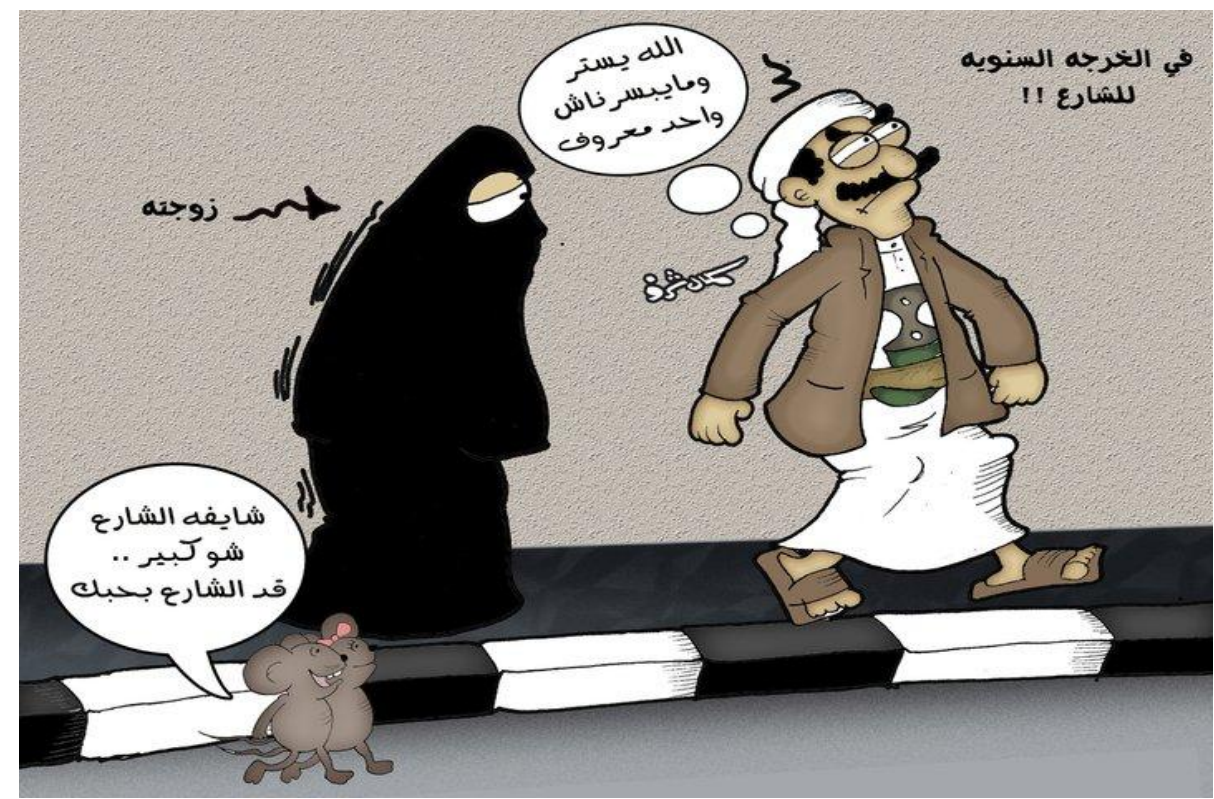

Figure 1.3 (Source: http://bit.ly/2KOXdtI)

\begin{tabular}{|c|c|c|c|c|c|c|}
\hline \multirow{2}{*}{ A man to himself } & Allah & yastir & wa māa & yabsirnāsh & waḥid & ma 'rūf \\
\cline { 2 - 6 } & God & protects & and not & see us & someone & familiar \\
\hline
\end{tabular}

\begin{tabular}{|l|l|l|l|l|l|l|l|}
\hline \multirow{2}{*}{ A mouse to its female partner } & Shaifa & alshari & sh $\bar{u}$ & kab $\bar{\imath} r$ & qad & alshari & bahibak \\
\cline { 2 - 7 } & seeing & the street & how & big & like & the street & love you \\
\hline
\end{tabular}




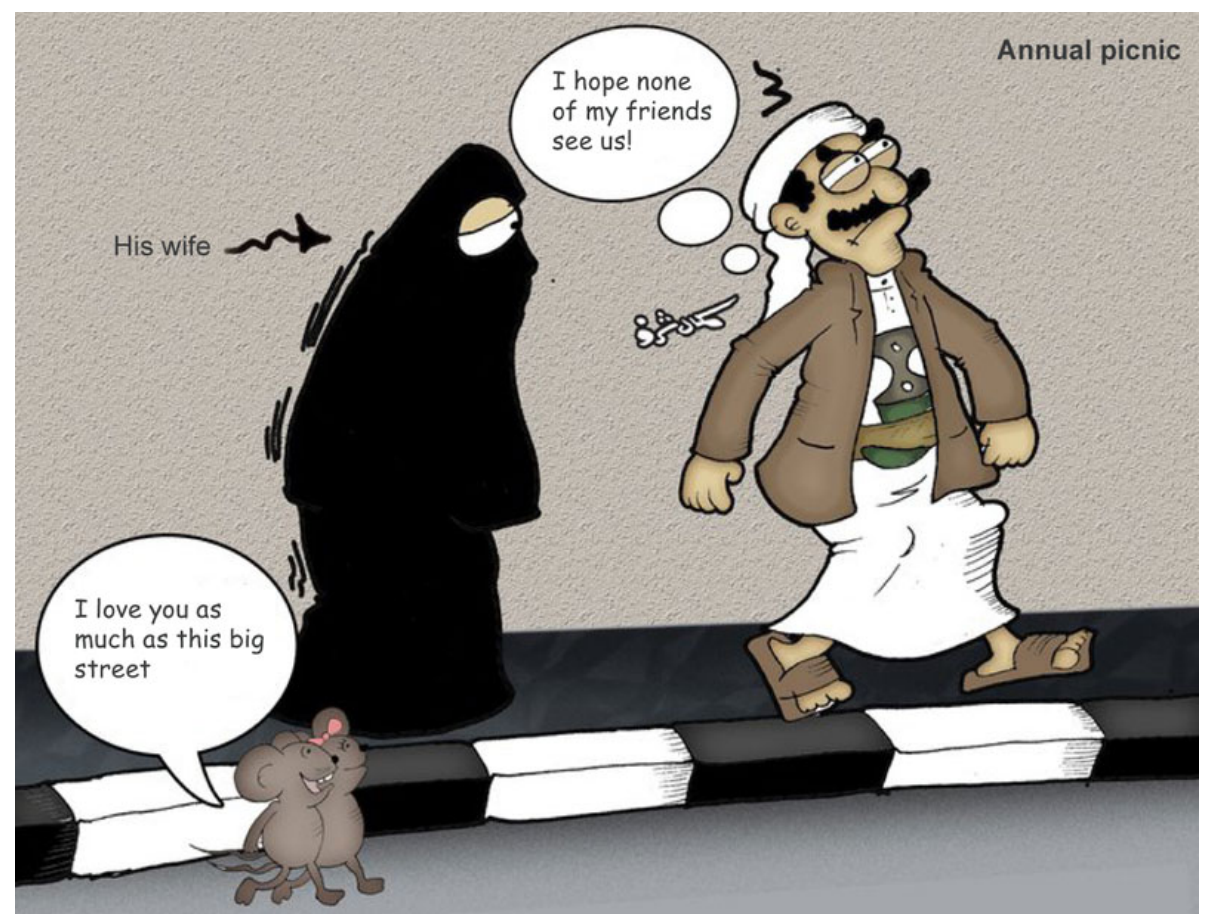

Figure 1.4 (Source: http://www.yementimes.com/)

The source of humour in the SC lies in the incongruous situation between the man who walks in front of his wife, hoping to God that nobody should see him in the company of his spouse and the mouse which does not hesitate to express his love to his partner. The cartoon highlights one aspect of the oppression of women in some parts of Yemen, where women rarely step out of their houses without a male companion. The caption at the top right corner of the SC reads yaum al-kharjah $a l-s a n w \bar{l}$, and has been rendered as "Annual picnic" in the TC. The translation has sacrificed the ideational meaning in the sense that having an annual picnic is very common throughout the world. However, what the cartoonist intends to say can be interpreted as an existential process, namely "There is only one annual outing for Yemeni women”. As for the man's caption, it has been translated as "I hope none of my friends see us!" but that may not be understood by a reader who is unfamiliar with the Yemeni culture. It can be transcoded as "It would be a shame if someone sees me with my wife. Let's hurry. I pray to you, my Lord, that nobody will see us together". The articulation of relational and mental processes in the first sentence, the material process in the second sentence, and the verbal and mental processes in the third sentence, has made this aspect of the oppression of women clear to an uninitiated reader.

At the interpersonal level, the phrase Allah yastir has been translated as "I hope". In fact, the phrase can evoke different interpretations, and it can be translated as "Heaven help!", "God forbids", and "May God save or protect us". However, the use of the phrase in Yemeni Arabic can be different. This term can be used to pray to God to conceal a shameful or wrong act from public eyes. So, it would be rendered more aptly as "I pray to you, my Lord".

As for the textual meaning, the translation of the cartoon in Figure 1.4 does not reflect the intersemiotic comparative relation that exists between the text and image. The caption and the image share similar experiential meanings. The image shows the man in his traditional Yemeni 
attire, turban and jumbia ${ }^{3}$ walking hurriedly for fear that others might see him walking with his wife in the street. The caption of the original cartoon is a different semiotic reformulation of the image (Kress 2010; Martin 1992). Similarly, the image of the mice and the caption reformulate the same logical relation. The male mouse is very happy as depicted by its broad smile, and it walks slowly with the female mouse, telling her "I love you as much as this big street". Although the translation in Figure 1.4 preserves the comparative intersemiotic relation between the visual image and the text, the target reader may find it difficult to understand the intention of the cartoonist. This can be made clear if the contrast relation that exists between the image and the text of both the man and the mouse is clarified. The man is reluctant to walk freely with his wife, even occasionally. He is leaving his wife behind in his hurry to remove himself from the public eye, and feels ashamed because he is walking with her; fear is very explicit in his demeanor. The mouse, however, seems happy, enjoying its daily walk in a leisurely fashion with its partner. "Let's go for our daily walk. I love you as much as this road, sweetie" could be a better translation than the translation in Figure 1.4. It may be argued that a target reader in English would possess the visual literacy to understand the cartoonist's intention as the contrast between the humans and mice is clear from the visual content of the cartoon. A reader may understand the cartoon as a critique of the conduct of an individual man behaving in a sexist way, rather than a critique of social practices in Yemeni society in general.

\subsubsection{Analysis of cartoon 3}

Another instance in which the three strands of meanings have been lost in the translation is given below.

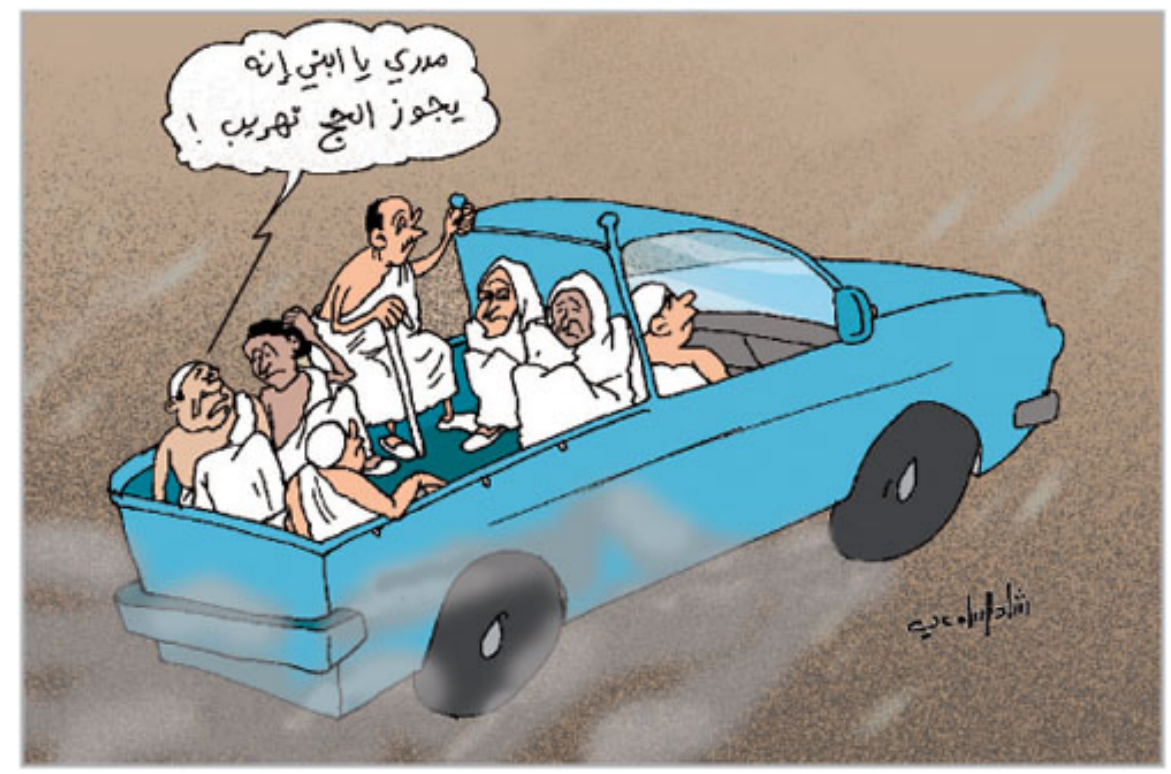

Figure 1.5 (Source: http://bit.ly/2NbLkeg).

\begin{tabular}{|c|c|c|c|c|c|c|}
\hline midr $\bar{\imath}$ & $y a$ & $i b n \bar{\jmath}$ & innuh & yajūz & al haj & tahr $\bar{\imath} b$ \\
\hline I wonder & vocative particle & son my & that & permitted & pilgrim & by smuggling \\
\hline
\end{tabular}

\footnotetext{
${ }^{3}$ A jumbia is a traditional curved dagger worn by Yemenis. It may have an ornamental handle made of rhino horn or a precious stone.
} 


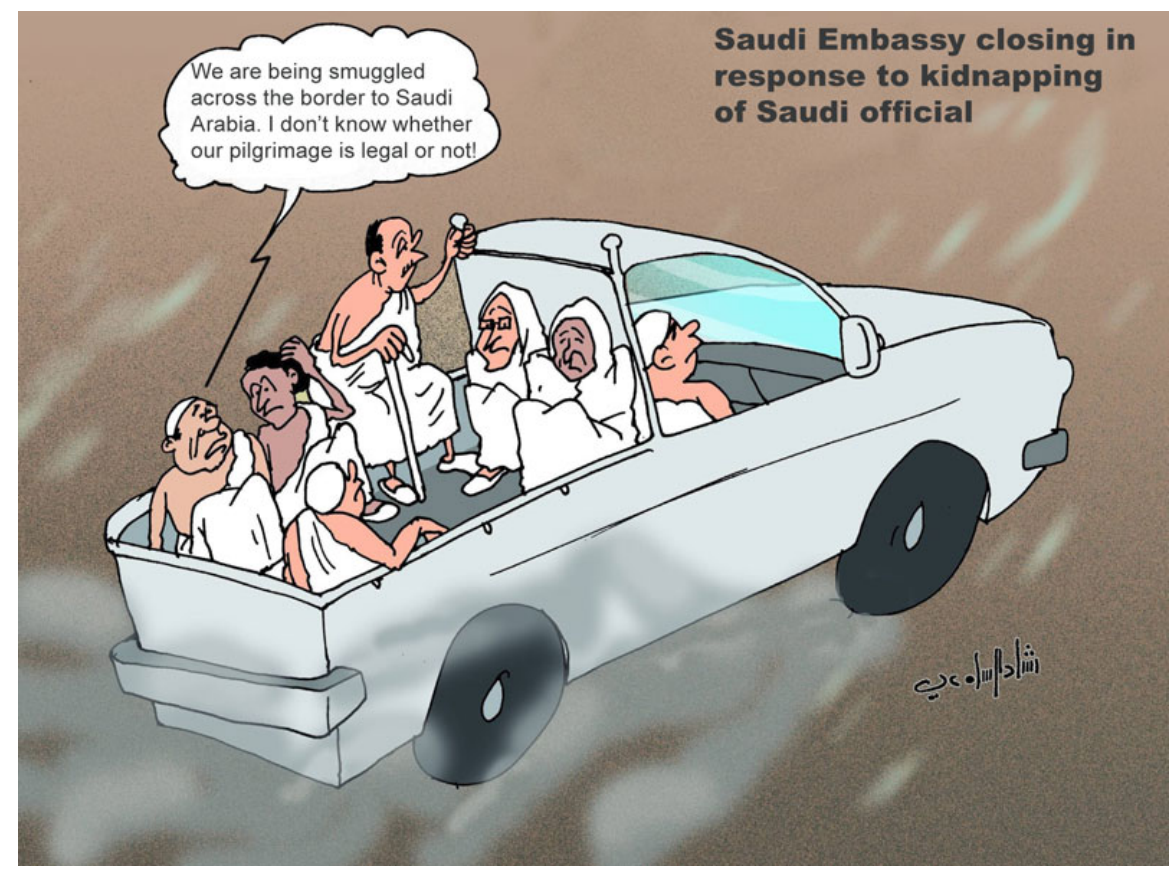

Figure 1.6 (Source: http://www.yementimes.com/)

During the annual Muslim pilgrimage, commonly known as haj, human smuggling becomes a thriving enterprise around the holy city of Mecca. The context of culture needs to be made clear from the beginning with a view to familiarising the target reader with the situational background of the cartoon.

Although the TC shows some background information by using the material process "Saudi Embassy closing in response to kidnapping of a Saudi official", this does not reflect the most relevant aspect of the context of culture. In fact, pilgrim trafficking across the Yemeni-Saudi borders is a flourishing business due to the fact that Saudi Arabia identifies a strict quota of pilgrims for each country, thus a lot of people who do not get the chance to go on pilgrimage become prey for human traffickers. With this in mind, the cartoon would be more communicative if this background information was made clear either through the use of some material processes, such as "Only few pilgrims are officially allowed to go on haj this year", or through the use of a verbal process, such as "Saudi authorities said a strict quota of pilgrims will be given the chance to go on haj". This background knowledge can clarify the mental process of one of the smuggled people who appears in the image asking a youngster, perhaps his son, "Do you think our Haj will be accepted if we are smuggled?”. This seems more apt than the translation given in the TC, where a relational process is used in a projected clause "I do not know whether our pilgrimage is legal or not!” In fact, haj cannot be legal or illegal. It can, however, be accepted or rejected.

A grammatical resource realising interpersonal meanings in the SC is the use of the interrogative mood, which obviously functions as "demand for information". The translation has retained this function through the use of a declarative mood, but the interpersonal relationship between the addresser (i.e., the old man) in the image, and the addressee (i.e., the youngster) is not retained in the translation. The informality of the SC represented by the vocative midri yabni could have been better preserved in the TC had the translator used the word "lad", which may be interpreted as a term of endearment. 
As far as the textual metafunction is concerned, the linguistic message clearly reformulates the corresponding image. The visual part of the cartoon shows a car with no license plate, which implies that the car is used in smuggling and human trafficking. The non-paved road adds another piece of evidence that it is an unusual route that smugglers use to evade border guards. The people in the back of the car are dressed in white, the dress of all pilgrims, and one of them clearly asks a person close by something. The question is linguistically articulated as midri yabni ('Do you think [...] lad?'). Thus, an intersemiotic comparative relation is in play in this cartoon (Liu and O'Halloran 2009). This aspect of intersemiotic texture needs to be considered in the translation of the cartoon. Thus, "My lad! Do you think that our haj will be accepted if we are smuggled?” not only maintains the ideational and interpersonal meanings of the cartoon but also preserves its intersemiotic texture more accurately than the translation given in the TC.

\subsubsection{Analysis of cartoon 4}

A fourth example of the problematisation of translation equivalence while translating cartoons is given below.

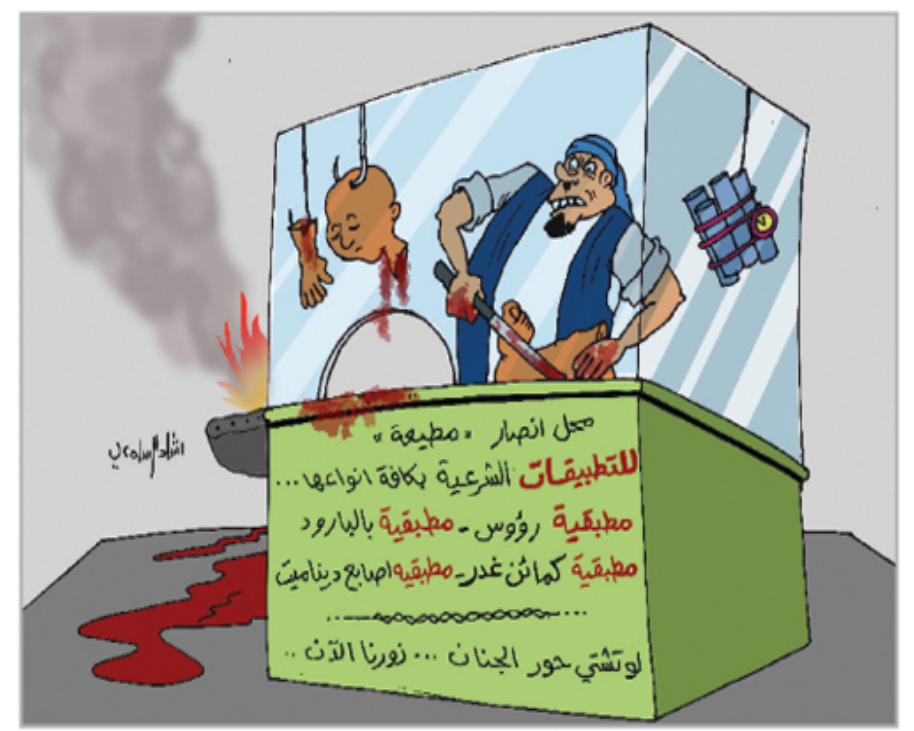

Figure 1.7 (Source: $\underline{\text { https://bit.ly/2Qs2OsF). }}$

\begin{tabular}{|c|c|c|c|c|c|}
\hline \multirow{2}{*}{ Name of shop } & mahal & Anșār & Muțī'ah & liltațbiqāt & al-shar 'iyah \\
\hline & shop & supporters & brainwashed & for wraps & Sharī'ah compliant \\
\hline
\end{tabular}

\begin{tabular}{|c|c|}
\hline bi-kafat & anwā' $a h$ \\
\hline with all & types \\
\hline
\end{tabular}

\begin{tabular}{|c|c|c|c|c|}
\hline mu țabaqiyat & $R u^{\prime} \bar{u} s$, & mu țabaqiyah & bi-al-barūd & uțabaqiyah \\
\hline wraps & heads & wrap & powders & wraps \\
\hline
\end{tabular}

\begin{tabular}{|c|c|c|c|}
\hline kamā' 'in ghadr & mu țabaqiyah & $a_{\text {șābi }}$ & dinam $\bar{\imath} t$ \\
\hline ambushes & wraps & fingers & dynamite \\
\hline
\end{tabular}

\begin{tabular}{|c|c|c|c|c|c|}
\hline Lau & tisht $\bar{\imath}$ & $H \bar{u} r$ & Al-jinān & zuranā & al 'ān. \\
\hline If & want you & women & the paradise & visit us & now \\
\hline
\end{tabular}




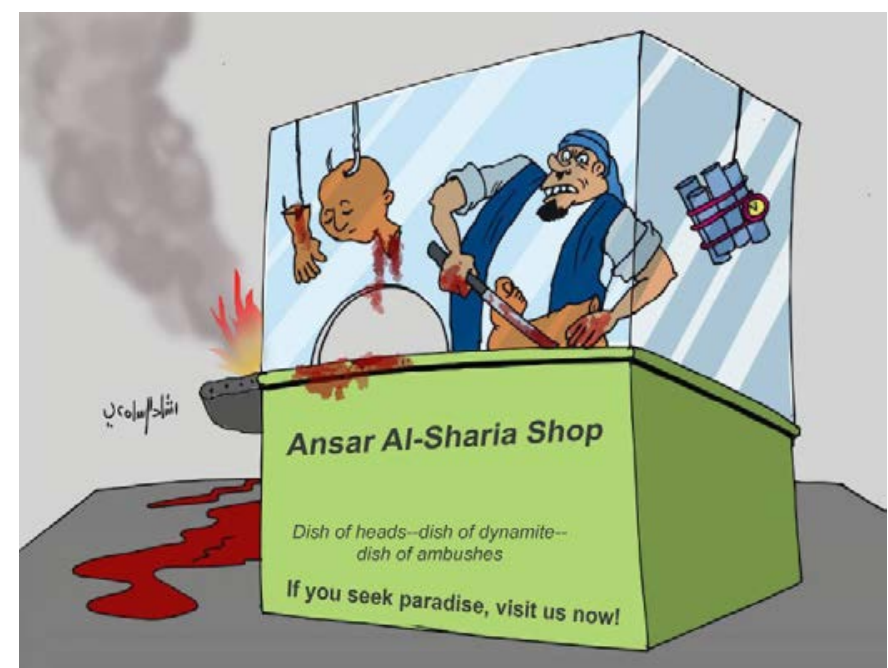

Figure 1.8 (Source: http://www.yementimes.com/)

The SC given above revolves around Anșār Al-Sharī'ah. This is a sub-group of Al-Qaeda known by the mass media as "Al-Qaeda in the Arabian Peninsula" (AQAP). This SC tackles one of the suicide operations by Al-Qaeda affiliates that horrified the Yemeni nation.

The translation of the cartoon undergoes a loss at the three metafunctions. The original cartoon depicts one of the members of Al-Qaeda as a butcher who is working in a shop branded as anșār Muti 'ah shop ('the brainwashed supporters' shop') to emphasise the fact that Al-Qaeda affiliates follow their leaders blindly. However, the translator has inappropriately used the substitution strategy and translated the brand name as "Anșār Al-Sharī'ah Shop”. The addition of a note such as "on the last destructive suicide operation of Al-Qaeda" will enable the reader to understand that the allusive expression Anșār Muțī $a h$ is used to refer to Al-Qaeda.

As is clear from the gloss, the original cartoon includes a wide use of nominalisation - a typical resource for grammatical metaphor (Halliday 1994) - but the translator has opted to use the reduction strategy, and has deleted the whole nominalised package in the translated cartoon. Here, grammatical demetaphorisation can be very significant in the process of comprehending the message. In other words, the translation will be more apt if we demetaphorise the heavy packaging of the clause as "The Brainwashed Youth Butchery and Restaurant serve different kinds of Halal meals. We offer (human) head platters and gunpowder platters. We supply all types of ambushes and dynamite baits". The sequence of clauses makes the comprehension of the message much easier.

As far as the interpersonal metafunction is concerned, the appraisal system of the SC is not retained in the translation. The appraisal system of Attitude, represented by the judgmental expression mahal Anșār muți 'ah, is translated as "Ansar Al-Sharī'ah shop”. Anșār Al-Sharī'ah ('Partisans of Islamic Law') is an ideological title widely circulated by the mass media. However, in interpersonal terms, it seems that the negative judgement conveyed by Anșār muti 'ah ('the brainwashed youth/supporters') is lost in the translation. Similarly, hiūr al-jinān ('beautiful women of Paradise') is reduced in the translation, and thus the appreciation and ironic use of the term is substituted by a more generic term, i.e., "paradise". Hür al-jin ān refers to the extremely beautiful women of paradise. The cartoonist ironically refers to the promise given by Al-Qaeda to the suicide bombers that they will be martyrs and will get married to fair and chaste women in 
the paradise, and thus they should not feel sad if they do not win a fair lady in this life. Therefore, it is not only the Attitude appraisal system that is lost in the translation but also the ideational meaning.

At the textual level, the analysis of logical cohesion across written and visual components helps the translator to produce a better translation of the cartoon. The multimodality of this cartoon shows that the image adds new information to the text. That is to say, there is a man who chops what appears to be a human foot using a blood-stained knife. In the shop, a head, a hand, and a bomb belt are hanging from meat hooks. Outside the shop, there is a devastating explosion as depicted by the flames of fire and the blood flowing on the floor. Thus, an intersemiotic additive relation (Liu and O'Halloran 2009) exists between the two modes. We should not, therefore, expect the target reader to be familiar with this coherence relation, meaning that basic details need to be made clear and supplemented by textual data such as "On the last destructive suicide operations of Al-Qaeda”. This will be sufficient to provide the target reader with the schema of this image, and the context of culture.

\subsubsection{Analysis of cartoon 5}

Another example of the problems involving the translation of cartoons is given in Figures 1.9 and 1.10 .

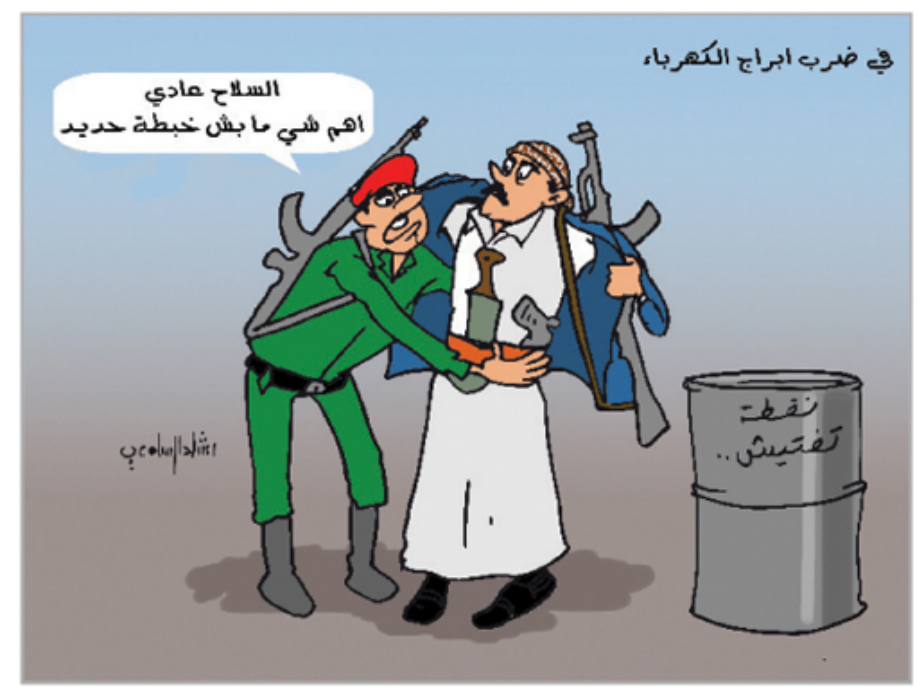

Figure 1.9 (Source: https://bit.ly/2BnYlgD).

\begin{tabular}{|c|c|c|c|c|}
\hline \multirow{2}{*}{ Top of the cartoon } & $f_{i}$ & $d a r b$ & ${ }^{\prime} a b r a \bar{j}$ & $A l-k a h r a b \bar{a}^{\prime}$ \\
\cline { 2 - 5 } & on & Attacking & towers & the electricity \\
\hline
\end{tabular}

\begin{tabular}{|c|c|c|}
\hline \multirow{2}{*}{ Barrel } & Noqțat & taft ìsh \\
\cline { 2 - 3 } & point & check \\
\hline
\end{tabular}

\begin{tabular}{|c|c|c|c|c|c|c|c|}
\hline \multirow{2}{*}{ Soldier to a tribesman } & Al silāh & 'ādi & aham & shai & ma bish & khabțat & hadìd \\
\hline & arms & normal & more importantly & thing & No & chain & Iron \\
\hline
\end{tabular}




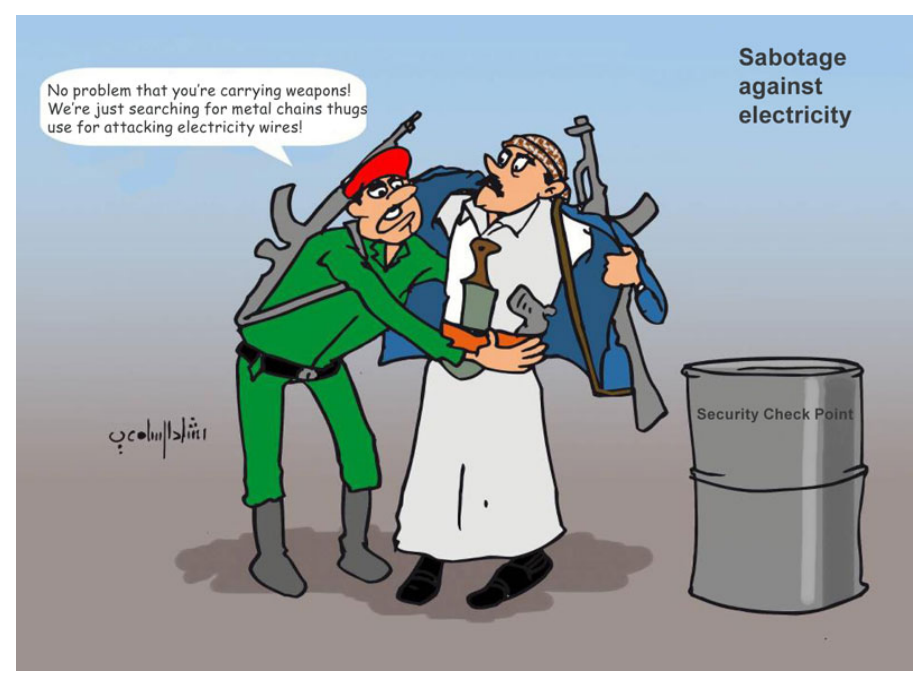

Figure 1.10 (Source: http://www.yementimes.com/)

It seems that the translator has translated the first part of the written component literally, and he/she added some information that can be retrieved from the visual component as well as the background information provided by the cartoonist in the SC. Hence, the translator has, to a great extent, rendered the ideational meaning satisfactorily. There is, however, some gain in translation when it comes to interpersonal metafunction, as we will see below. The incongruity of the SC lies in the fact that the security officer is overlooking the weapons the tribesman is carrying, and is instead searching for iron chains. The target reader should know what kind of vandalism the cartoonist is talking about, i.e., the frequent attacks on electricity towers. In June 2012, saboteurs repeatedly threw iron chains onto the unattended electricity lines that link Marib Power Station with almost all Yemeni provinces. In doing so, they vandalised these power lines so that they no longer transmitted electricity. The attacks on power lines took place repeatedly in the region of Al-Gad 'an, between Marib and the capital Sana'a, with the result that it often plunged most of the Yemeni provinces into darkness. Therefore, the security officer is looking for iron chains and not for weapons. The translation would be clearer then if the translator translated the background information given by the cartoonist, i.e., fi $\mathrm{l}$ arb 'abrāj al$k a h r b \bar{a}^{\prime}$ ('on the attacks on electricity towers') as "In Yemen, saboteurs frequently attack electricity towers with iron chains".

As for the interpersonal metafunction, the Attitude Judgment system of appraisal ${ }^{4}$, represented by the word "thug" in the TC, does not exist in the SC. During the Arab Spring, the word "thug" was used as an equivalent to the Arabic word balțaji , which has very negative political connotations in the Yemeni and Arab societies as it is associated with anti-revolution elements. However, the perpetrators targeting the power lines were not always driven by political intentions. They usually demanded some kind of compensation from the government and they claimed that they were deprived of basic services. The interpersonal meaning would thus be better rendered through modality as, for example, "You can move around with arms, but you must not carry iron chains". As suggested earlier, the translation of the caption in the right corner of the cartoon has already made it clear that iron chains were used to sabotage electricity towers. Unlike the TC, no affective attitudinal meaning is triggered in the above suggested translation.

\footnotetext{
${ }^{4}$ Attitude is a resource of language that enables us to express our attitude(s) towards people, events, and other phenomena. Attitude is expressed through words of appreciation, judgement, or emotion.
} 
At the textual level, the written component reformulates the visual component. A security officer is searching the tribesman carefully, looking for a metal chain but ignoring the fact that the tribesman is carrying a gun, a pistol and a jumbia. Hence, "You can move around with arms, but you must not carry iron chains" preserves not only the ideational and interpersonal metafunctions of the SC but also the parallel multimodal relation between the visual and written modes.

\subsubsection{Analysis of cartoon 6}

Cartoon 6 tackles the problem of the water crisis in Taiz, one of the most populous cities in the country, and one of the most water-stressed cities in the world, where water supplies suffer critical shortages. Despite the fact that the municipality rarely supplies houses with water, the bills are regularly sent on time.

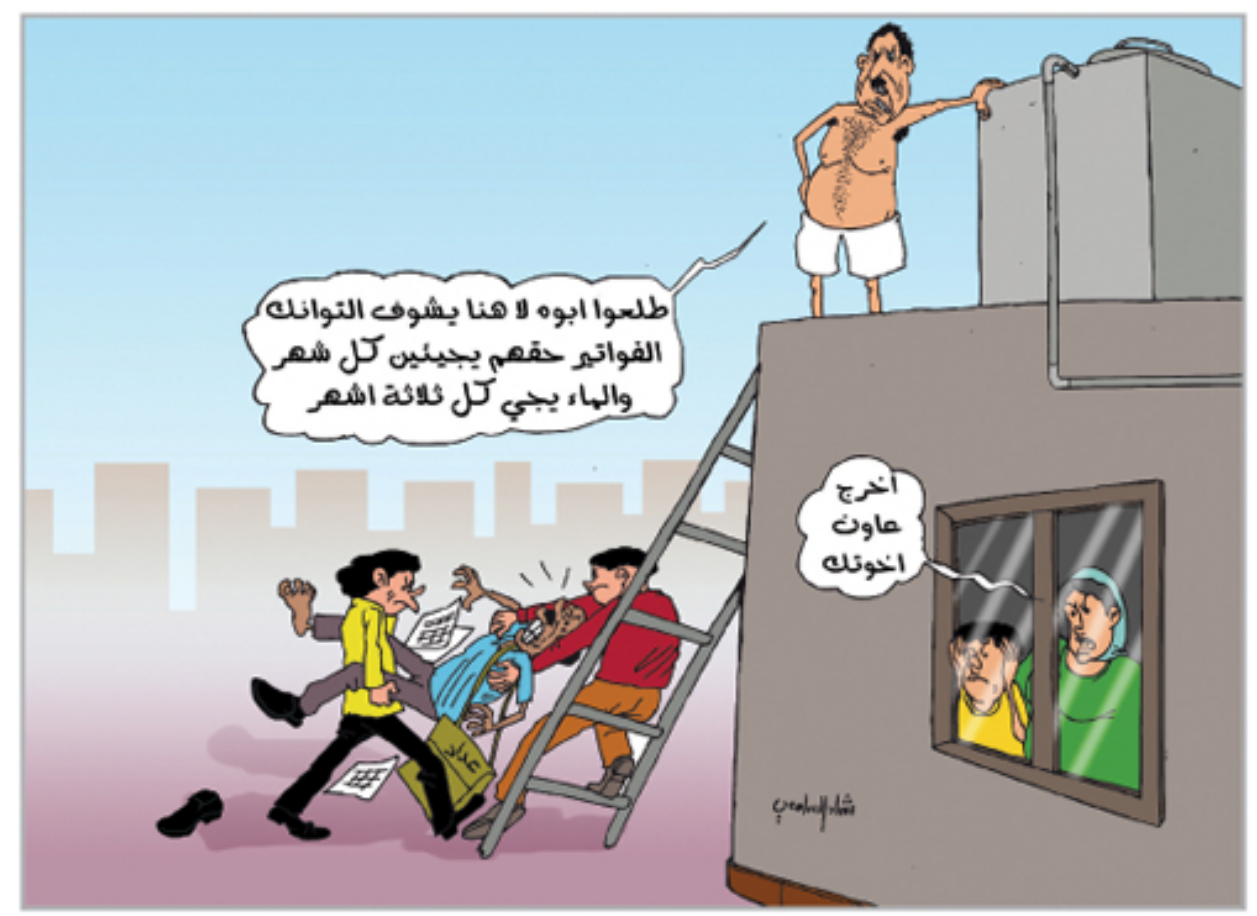

Figure 1.11 (Source: https://bit.ly/2RWQBsH).

\begin{tabular}{|c|c|c|c|c|c|c|}
\hline \multirow{2}{*}{ Father to his sons } & $\operatorname{tali}^{\prime} \bar{u}$ & $a b \bar{u} h$ & la hunā & yashūf & al tawānik. & Alfawātīr \\
\cline { 2 - 7 } & Pull up & his father & here & see & the tanks & the invoice \\
\hline
\end{tabular}

\begin{tabular}{|c|c|c|c|c|c|c|c|c|}
\hline haqahum & yaj̄' in & kul & shahr & wa alma $\bar{a}$ & yajī & kul & thalätha & ashhur \\
\hline their & comes & every & month & and water & comes & every & three & months \\
\hline
\end{tabular}

\begin{tabular}{|l|l|l|l|}
\hline \multirow{2}{*}{ Mother to her son } & $i k h r u j$ & 'awin & akhwatak \\
\cline { 2 - 4 } & Go out & help & brothers your \\
\hline
\end{tabular}




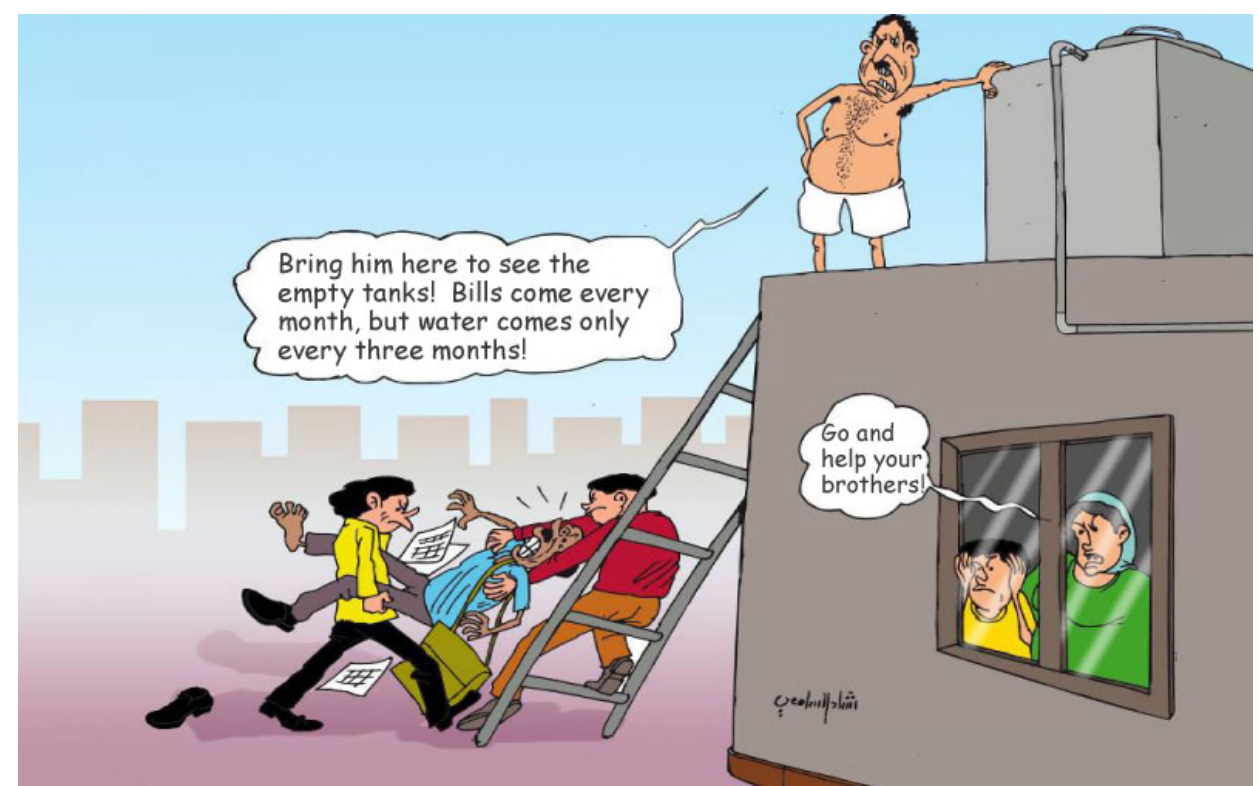

Figure 1.12 (Source: http://www.yementimes.com/)

The TC has conveyed the ideational meaning of the SC to a great extent, but it may be difficult for a target reader who is not quite familiar with Yemeni society and the water crisis that strikes the country to understand fully the ideational message of the SC. For instance, the fact that Yemeni houses tend to have water tanks on their roofs that are fed by a municipal water supply might not be obvious to a target reader.

What the man on the roof says has been rendered perfectly through the literal translation strategy. However, what the two boys at the foot of the ladder are doing may not be accessible to a target reader. On the ground, these two boys are attacking a person and trying to pull him up the ladder. The man who is being attacked is a water corporation employee whose sole job is to read the meters. The translation would be clearer if the goal of the material clause tali ' $\bar{u}$ 'bū la-hunā ('pull him up') was translated as "this (bad) meter reader" rather than "him”. It is clear from the image that the two boys are pulling someone up, but the disclosure of the man's identity makes the TC more communicative.

The interpersonal meaning in the cartoon has also not been translated appropriately. The translator has used the reduction strategy and reduced the word $\bar{a} b \bar{u} h$ ('his father'), which plays a vital role in the creation of humour and the funniness of the text. $\bar{A} b \bar{u} h$ is a common swear word and an expression of anger associated with the Taizi variety of Yemeni Arabic. The use of an affective word like "bad meter reader" would retain the same force of the original even if the colloquial swear word $\bar{a} b \bar{u} h$ is substituted by a more neutral and standard term in the target language. Alternatively, an expression like "this crook" can be used. Another alternative would be to put in a censored swear word in English, e.g. 'this $* * * * * *$ meter reader', where the asterisks indicate that a swear word has been deleted.

In addition, the multimodal textual links between pictures and captions are central in creating the humour of this cartoon and they must be considered in translation. The image and written text convey related but different messages. The coherence relation between the two figures is an intersemiotic additive relation. A half-naked, angry man on the roof of his house is checking the empty tanks, and he commands his two sons to force the water corporation employee to come up 
and check the tanks himself. A mother is watching from the window of the house, and she commands her child standing next to her to go and help his brothers as if they were doing a heroic act.

\subsubsection{Register analysis of the six cartoons}

In this subsection, we attempt a register analysis of the six cartoons. The six cartoons are similar in a number of register aspects, and hence we opt for having one section for the analysis of all cartoons. Having a (register) analysis for each cartoon, as we have done with the metafunctional analysis above, will render the analysis monotonous.

Comparing the SCs and TCs, we can say that Field remains similar in all translated cartoons. In (1), both the SC and TC relate the Yemeni tradition of celebrating marriage and, in particular, the bizarre tradition of firing guns into the sky. In (2), both the SC and TC deal with one aspect of discrimination against women in the Yemeni society, namely that women hardly step out of their homes without male companions. Even worse, a companion (i.e., the husband) is averse to walk together with his wife in view of the public.

In (3), both the SC and TC describe the common phenomenon of smuggling pilgrims across the Yemeni-Saudi borders due to Saudi authorities' strict quota measures which restrict the numbers of pilgrims in each country. In (4), both relate the story of Al-Qaeda's suicide operations. In (5), both comment on the vandalism of electricity towers in Yemen, and they criticise the widespread phenomenon of carrying arms in Yemen where more than 60 million unlicensed units are in the possession of the citizens. Finally, in (6), both report on the water crisis in Yemen, especially in the southern province and populous city of Taiz.

Nevertheless, there are mismatches in the amount of information that is given in the TCs. In Figure 1.2, for instance, we are clearly informed that any delay in hurrying away from the celebratory gun-firing situation will cost the bird its life. Similarly, in Figure 1.6, although there is no reference to the Saudi Embassy in the SC, a full declarative sentence has been added, i.e., "Saudi Embassy closing in response to kidnapping of Saudi official". In a similar vein, Figure 1.8 does not show that the menu is Sharī'ah compliant, thus criticising Al-Qaeda which kills innocents in the name of religion. Again, the menu is also reduced and some terms have been omitted in the TC, as we have discussed in the section above. Unlike the SC, the TC in Figure 1.10 does not refer to balatijah ('thugs') and the police's words are clear in this cartoon. As for the social action and the granularity of lexical items, we can argue that they are general and popular.

There is a similar story as far as Mode is concerned: in both cases the cartoons are sketched/written and translated to be read and visualised. The comprehension of the message depends on both the text and the image, and thus the medium is complex.

The mode of participation is also complex. All cartoons are sketched in a dialogue form: a dialogue between a policeman and a tribesman, as shown from their attire (Figures 1.9 and 1.10), a dialogue between a father and children (Figures 1.11 and 1.12), and a dialogue between the two mice (Figures 1.3 and 1.4). Even in the case of monologues (as in Figures 1.1 and 1.2) and the monologue of the man in Figures 1.3 and 1.4, there is still a lot to be deduced from both the text and image. 
As far as the Tenor of the SCs and TCs is concerned, the illustrators of the SCs (i.e., Rashād Al-Sami ' $\overline{1}$ and Kamāl Sharaf) are both artists, and political and social activists who have tackled a number of social and political issues in their community through cartoons. The author's provenance might be different in the TCs as the translator might not be an artist: he/she might be a journalist or a translator who was commissioned to do the translation.

The rendition of social attitude is perhaps the most problematic element. The social dialect used in the cartoons shows clearly that the authors either speak the Taizi variety of Yemeni Arabic - clearly reflected in the use of expressions such as khif arjulak (Figure 1.1), tali ' $\bar{u}$ 'bu la-huna (Figure 1.11), lau tishtī (Figure 1.7), and midrī (Figure 1.5) - or the Sanani dialect, as illustrated by the use of $m \bar{a}$ bish (Figure 1.11) and rabanna yistir (Figure 1.3) which are not used in other Yemeni dialects of Arabic. The TCs show mismatches of this aspect in the sense that the above terms/expressions are either replaced by standard or formal terms/expressions in the TCs or they are completely lost in the translation. For instance, although the expression "Run for your life!" in Figure (1.2) is usually used informally in English, it does not retain the force of the casual expression of the original khif arjulak (Figure 1.1). This is what makes "Shake a leg" a more faithful translation. In short, most of the cartoons tend to be informal as they abound in the use of informal colloquial words, and this is where most of the translations mismatch.

\subsubsection{Genre analysis}

The genre seems to be interpreted in a similar manner in the SCs and TCs. This is already evident in the fact that the translators have preserved the original visual components of all cartoons: they have used the same drawings, only altering the written text. They use certain strategies, such as hyperbole, humour and satire, to challenge authority and to tackle key social and political issues such as marriage, terrorism, vandalism, human trafficking, the Taizi water crisis, and domestic violence. The fact that the English genre abounds in the use of some written commentaries to help the target reader understand the message of the SCs does not affect the genre of the cartoons in any way. The use of these commentaries seems unavoidable in the translation of cartoons. A possible difference between editorial and/or political cartoons in Arabic and English is that Arab cartoonists tend to associate their cartoons with some written messages; Western cartoonists, on the other hand, rarely include any written messages or contextual clues (Al-Labād and Hajāj 2005). Thus, the comprehension of the message of Western cartoons requires further effort on the part of the reader.

\section{Discussion and conclusion}

This study has attempted a holistic approach to translating cartoons that stems from Halliday's (1994) SFL and House's (1977/1997) SFL-based translation model. A bottom-up analysis of six SCs and TCs was conducted and appears in the above subsections. The study concludes that if a cartoon is to be translated in such a way that the TC sounds as natural and entertaining to the target audience as the SC, the translator should take into account the context of culture, the context of situation and the metafunction(s) involved in the SC, and should try to render them as far as possible in the target language.

In fact, ideational problems and context-specific problems receive more attention in the process of translation because the ideational metafunction is typically considered to carry the highest 
value simply because translation equivalence is often defined in ideational terms to such a degree that if a target text does not match the source text from an ideational perspective, it is not even considered a translation (Halliday 2001; Manfredi 2008; Mohammed 2011; Setiajid 2008). This does not mean, however, that a translator should underestimate the value of other metafunctions. Sometimes the interpersonal metafunction can play a vital role in the creation of humour, and a translator might easily render the ideational meaning, but interpersonal meanings may be completely lost in the translation, as we have seen in the analysis of informal expressions in the cartoons for this study. At other times, the translator's focus on ideational meaning may lead him/her to use terms that sacrifice the interpersonal meanings intended by the cartoonists.

In addition, the relation between the image and written text in this multi-semiotic or multimodal genre can facilitate the comprehension of the context and the interpretation of the schemata of a cartoon. The translation of a cartoon cannot be achieved unless multi-semioticity or multimodality is considered. The intersemiotic relation between the text and image can force the translator to adopt various strategies to rewrite and recreate a cartoon that retains the communicative force of the original cartoon.

Register variables have also undergone some kind of mismatch or loss in the TCs. For instance, the Field of the cartoons has been retained to a great extent, but the presentation of information differs in the TCs. Similarly, while the visual component of the cartoons remains intact, longer written messages are used in the TCs, and this is sometimes unavoidable. In other words, the visibility of the translator is obvious in the translation of cartoons, no matter how creative a translator is. The lack of equivalent colloquial terms or expressions of the SCs within the TCs creates some kind of loss at the Tenor level, even though symmetry between the addressors and addressees is not disturbed.

Translation equivalence should therefore be sought at the levels mentioned above, and each cartoon should be taken on an individual basis with a view to facilitating the functional equivalence between the SC and its translation. A translator of cartoons is required to investigate the metafunctions which are prevalent in the SC and preserve them in the target language. In addition, translation is a process of contexualisation and recontextualisation, and thus the original context of a cartoon must be made clear to the target audience.

\section{Acknowledgements}

The authors thank the anonymous reviewers for their valuable comments and suggestions to improve the quality of the paper.

\section{References}

Abril, C.A.H. 2016. Análisis de los rasgos lingüísticos de Maus y sus interferencias en la traducción al español. TranscUlturAl: A Journal of Translation and Cultural Studies 8(2): 2441. https://doi.org/10.21992/T99S5W

Al Minawi, H. 2016, September 25. Șurat al-karikatīr alatī tasababat fì maqtal al-kātib al-urdunī Nāhiḍ Hatar [The cartoon that caused the murder of the Jordanian writer, Nāhị̣ Hatar]. Available online: http://bit.ly/2N3JT1l (Accessed 9 January 2018). 
Al-Hayjami, S. 2014, November 23. fan al-Karīkatīr wa durahu fī nahḍat al-thaqafah al'arabiyah: Sakhir wa qadīm ... gh' ab hadir [The art of cartoon and its role in the development of the Arabic culture: Sarcastic and ancient ... Absent and present]. Available online: http://alhakk.net/2012-03-31-18-36-46/2012-03-31-19-01-18/53-2012-03-31-17-31-55/81422014-10-23-19-00-51.html (Accessed 9 January 2018).

Al-Jumhūriyah. 2008, November 23. fì ḥalaqat niqāsh fī 'adan: fan al-Karīkatīr fĩ al-ṣaḥāfah Al-Yaminyah [The caricature art in the Yemeni Press]. Available online: http://www.algomhoriah.net/atach.php?id=18860 (Accessed 9 January 2018).

Al-Labād, M.-D., and 'imād Ḥajāj . 2005, March 18. Al-Karyākātīr Al-Siyāsī wa al-ta 'bīr 'an qazyā al-umah [Political cartoon as a manifestation of the Nation's Issues] [Al-Jazeera Arabic (TV channel)]. Available online: http://bit.ly/2m8OcNp (Accessed 9 January 2018).

Aragao, S.M. 2016. La imagen y el texto en Le Photographe: una reflexión sobre fotoperiodismo, cómics y traducción. TranscUlturAl: A Journal of Translation and Cultural Studies 8(2): 128-153. https://doi.org/10.21992/T9J91Q

Assis, E. 2016. The concept of fidelity in comics translation. TranscUlturAl: A Journal of Translation and Cultural Studies 8(2): 8-23.

Baker, M. 1992. In other words: A course on translation. London and New York: Routledge.

Borodo, M. 2016. Exploring the links between comics translation and AVT. TranscUlturAl: A Journal of Translation and Cultural Studies 8(2): 68-85. https://doi.org/10.21992/T9XK9X

Catford, J.C. 1965. A linguistic theory of translation (Vol. 31). London: Oxford University Press.

Corstange, D. 2007. Drawing dissent: Political cartoons in Yemen. Political Science \& Politics 40(2): 293-296. https://doi.org/10.1017/S1049096507070461

Cui, S. 2012. Creativity in translating cartoons from English into Mandarin Chinese. The Journal of Specialised Translation (17): 124-135.

Eggins, S. 2004. Introduction to systemic functional linguistics. London: A\&C Black.

El-Arousy, N.A. 2007. Towards a functional approach to the translation of Egyptian cartoons. Humour - International Journal of Humour Research 20(3): 297-321. https://doi.org/10.1515/ $\underline{\text { HUMOR.2007.015 }}$

Fabbretti, M. 2016. The use of translation notes in Manga scanlation. TranscUlturAl: A Journal of Translation and Cultural Studies 8(2): 86-104. https://doi.org/10.21992/T9SS57

Falco, G. 2016. Econocomics: Teaching translation of economic and financial texts through comics. TranscUlturAl: A Journal of Translation and Cultural Studies 8(2): 105-127. https://doi.org/10.21992/T98S6Z 
Guyer, J. 2016. Translating Egypt's political cartoons. In M. Baker (Ed.) Translating dissent: Voices from and with the Egyptian revolution. London: Routledge. pp. 208-222.

Halliday, M.A.K. 1978. Language as social semiotic. London: Arnold.

Halliday, M.A.K. 1994. Functional grammar. London: Edward Arnold.

Halliday, M.A.K. 2001. Towards a theory of good translation. In E. Steiner and Yallop (Eds.) Exploring translation and multilingual text production: Beyond content. Berlin and New York: Walter de Gruyter. pp. 13-18. https://doi.org/10.1515/9783110866193.13

Halliday, M.A.K. and C.M. Matthiessen. 2004. Introduction to functional grammar. London: Edward Arnold.

Halliday, M.A.K. and R. Hasan. 1985. Language, context and text: Aspects of language in a social-semiotic perspective. Australia: Deakin University Press.

Hatim, B. 2001. Teaching and researching translation. Harlow: Pearson Education Limited.

Hellgren, E. 2007. Translation of Allusions in the Animated Cartoon 'The Simpsons'. MA thesis. University of Helsinki.

Hodge, R. and G. Kress. 1988. Social semiotics. Cambridge: Polity Press.

House, J. 1977. A model for translation quality assessment. Tubingen: Gunter Narr.

House, J. 1997. Translation quality assessment: A model revisited (Vol. 410). Gunter Narr Verlag.

Judickaitè-Pašvenskienè, L. 2014. The translation of idioms in children's cartoons: A comparative analysis of English dialogues and Lithuanian subtitles. Eesti Rakenduslingvistika Ühingu Aastaraamat 10(0): 125-138. https://doi.org/10.5128/ERYa10.08

Kenevisi, M.S. and M.S. Sanatifar. 2016. Comics polysystem in Iran: A case study of the Persian translations of Les Aventures de Tintin. TranscUlturAl: A Journal of Translation and Cultural Studies 8(2): 174-204. https://doi.org/10.21992/T9DK98

Koponen, M. 2004. Wordplay in Donald Duck Comics and their Finnish Translations. MA thesis. University of Helsinki.

Kress, G. 2010. Multimodality: A social semiotic approach to contemporary communication. London: Routledge.

Kress, G. and T. Van Leeuwen. 2006. Reading images: The grammar of visual design (2nd ed.). London: Routledge. https://doi.org/10.4324/9780203619728 
Leppihalme, R. 1997. Culture bumps. An empirical approach to the translation of allusions. Clevedon: Multilingual Matters.

Liu, Y. and K.L. O’Halloran. 2009. Intersemiotic texture: Analyzing cohesive devices between language and images. Social Semiotics 19(4): 367-388. https://doi.org/10.1080/ $\underline{10350330903361059}$

Macková, M. 2012. Specifics of Comics Translation. MA thesis. Masaryk University.

Manfredi, M. 2008. Translating text and context: Translation studies and Systemic Functional Linguistics. Volume 1: Translation theory. Bologna: Asterisco.

Martin, J.R. 1992. Genre and literacy-modeling context in educational linguistics. Annual Review of Applied Linguistics 13: 141-172. https://doi.org/10.1017/S0267190500002440

Martin, J.R. 2002. Meaning beyond the clause: SFL perspectives. Annual Review of Applied Linguistics 22: 52-74. https://doi.org/10.1017/S026719050200003X

Mohammed, T.A.S. 2011. A Taxonomy of Problems in Arabic-English Translation: A Systemic Functional Linguistics Approach. PhD thesis. University of the Western Cape.

Munday, J. 2001. Introducing translation studies: Theories and applications. London: Routledge.

Newmark, P. 1977. Communicative and semantic translation. Babel: International Journal of Translation 23(4): 163-180. https://doi.org/10.1075/babel.23.4.07new

Nida, E.A. 1964. Toward a science of translating: With special reference to principles and procedures involved in Bible translating. Leiden: Brill Archive.

O’Halloran, K. 2005. Mathematical discourse: Language, symbolism and visual images. London and New York: Continuum.

O’Halloran, K. 2007. Systemic functional multimodal discourse analysis (SF-MDA) approach to mathematics, grammar and literacy. In A. McCabe, M. O’Donnell and R. Whittaker (Eds.) Advances in language and education. London and New York: Continuum. pp. 77-102.

RT Arabic. 2016, September 26. Rasām Karīkatūr Maghribī yatalaqā tahdīdan bi-al-qatl ba 'd nashrị̣̄i rasman tasababa bi-īghtiyāl Nāhị̣ Hatar [ A Moroccan cartoonist received death threats for re-tweeting a cartoon that led to the assassination of Nāhị̣ Hatar]. Available online: http://bit.ly/2mbG3rKart (Accessed 9 January 2018).

Setiajid, H.H. 2008. Sociosemiotic approach in translation: Two models revisited. Available online: http://bit.ly/2mEVqsL (Accessed 17 March 2018).

Sharaf, K. 2013, October 7. The voices of caricature art [La Voix du Yémen]. Available online: http://www.lavoixduyemen.com/en/2013/10/07/the-voices-of-caricature-art-2/5083/

(Accessed 17 March 2018). 
Sun, H. 2011. On cultural differences and translation methods. Journal of Language Teaching \& Research 2(1): 160-163. https://doi.org/10.4304/jltr.2.1.160-163

Taran, T. 2014. Problems in the translation of comics and cartoons. Analele Shtiintifice, Universitatea de Studii Europene din Moldova 3: 90-101. Available online: https://ibn.idsi.md/ sites/default/files/imag file/90_100_Problems\%20in\%20the\%20translation\%20of\%20comics \%20and\%20cartoons.pdf (Accessed 13 December 2018).

Todd, R.W. 2012. Creating humour in Gary Larson's Far Side cartoons using interpersonal and textual metafunctions. In F. Bramlett (Ed.) Linguistics and the study of comics. London: Palgrave Macmillan. pp. 37-58. https://doi.org/10.1057/9781137004109_3

Yakin, O. 1999. Translation of Humour with Special Reference to the Cartoons in 'Leman' and Other Popular Weekly Humour Magazines of Turkey. PhD thesis. University of Warwick.

Yule, G. 2014. The study of language. Cambridge: Cambridge University Press.

Zanettin, F. 2010. Humour in translated cartoons and comics. In D. Chiaro (Ed.) Translation, humour and the media. New York: Bloomsbury Publishing. pp. 34-52.

Zyglis, A. 2003. The Art of Editorial Cartooning. Senior Honours thesis. Canisius College, Buffalo, NY. 


\section{Appendix}

ROTAS Table of Transliteration (source http://rotas.iium.edu.my/?Table_of_Transliteration) Table 1: Transliteration Table: Consonants

\begin{tabular}{|c|c|c|c|}
\hline Arabic & Roman & Arabic & Roman \\
\hline ب & $b$ & $b$ & $\mathrm{t}$ \\
\hline$\Xi$ & $\mathrm{t}$ & 5 & $z$ \\
\hline$\Xi$ & th & $\varepsilon$ & t \\
\hline 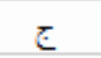 & $\mathrm{j}$ & $\dot{\varepsilon}$ & gh \\
\hline$\tau$ & $\mathrm{h}$ & فـ & f \\
\hline$\check{c}$ & $\mathrm{kh}$ & ق & q \\
\hline 3 & $d$ & 3) & $k$ \\
\hline 3 & dh & $J$ & I \\
\hline j & $r$ & 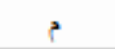 & $\mathrm{m}$ \\
\hline j & $z$ & $\dot{0}$ & $n$ \\
\hline س & 5 & $\lambda$ & $\mathrm{h}$ \\
\hline$\dot{v}$ & sh & 9 & $w$ \\
\hline$\rho$ & ș & G & , \\
\hline ض & $\stackrel{d}{d}$ & ي & $y$ \\
\hline
\end{tabular}

Table 2: Transliteration Table: Vowels and Diphthongs

\begin{tabular}{|c|c|c|c|}
\hline Arabic & Roman & Arabic & Roman \\
\hline- & $a$ & $\begin{array}{c}s \cdot 1 \\
s, 1\end{array}$ & an \\
\hline$A$ & u & s & un \\
\hline r & i & 5 & in \\
\hline .'5. & $\overline{\mathrm{a}}$ & $\xi$ & aw \\
\hline 3 & $\overline{\mathrm{u}}$ & ي & $a y$ \\
\hline \multirow[t]{2}{*}{ 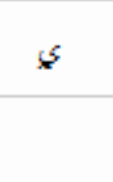 } & $\overline{1}$ & $\dot{s}$ & $\begin{array}{c}\text { uww, } \bar{u} \\
\text { (in final position) }\end{array}$ \\
\hline & & s & $\begin{array}{c}\text { iy, i } \\
\text { (in final position) }\end{array}$ \\
\hline
\end{tabular}

